\title{
Ethical Dimension \\ of Time in Plato's \\ Apology of Socrates
}

ARTUR PACEWICZ / Wroctaw /

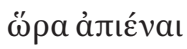

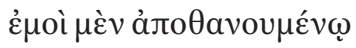

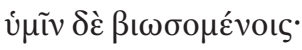

(Ap. 42 a 2-3)

\section{Introduction}

The aim of this paper is to present the ethical aspect of time in Plato's Apology of Socrates. Traditional approaches to the problem of time in Plato's philosophy focus on its ontological and epistemological dimension. The subject of analysis is the dialogue Timaeus in this case, in which time is the eternal picture of the eternal being (Tim. $37 \mathrm{~d}-\mathrm{e}$; Callahan 1948). But the close relationship between time and the moral order can already be seen in the pre-philosophical age, because it can be stated that every disorder in the time arrangement of human life is accompanied by disastrous results. Certainly it is not by accident that the Greeks have named three divine Horae (Hours): Eunomia (Good order), Dike (Justice) and Eirene (Peace). It can be stated that the concepts of justice and 
the moral order were closely bound up with the constant order of time, not only in the early period of Greek culture, but long before the beginning of philosophical speculation (Lloyd 1987: 215).

It is a well-known fact that everyone who undertakes an analysis of the Apology of Socrates (or the so-called Socratic dialogues at all) should be aware of the methodological problem called the Socratic question. Three positions can be set apart in it: two extreme ones, and a middle one:

1. The whole content of the Socratic dialogues should be ascribed to the historical Socrates;

2. The whole content of the Socratic dialogues should be attributed to Plato;

3. Some views in Plato's early dialogues are Socratic and some are Platonic ${ }^{1}$.

It seems to me that the problem is probably unresolvable, and maybe it is not important to solve it at all, because it is possible to read the text and analyze its ideas without determining who has really formulated them in the history of philosophy. But it can be noteworthy that the analysis can be made on rhetorical and philological, or on philosophical grounds. The difference between them can easily be seen when one considers the structure of the Apology. Aristotle in his Rhetoric (Rh. 1414 a 29-b 9) says that there are only two necessary parts of a speech:

1. statement of the case (лро́ $\theta \varepsilon \sigma ı \varsigma) ;$

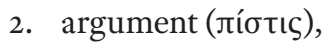

to which can be added:

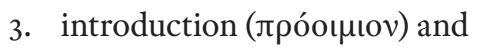

4. epilogue ('̇лí

From the philosophical point of view the arrangement of the parts can be regarded differently (Reeve 1989: 3):

1. opening address $(A p .17$ a $1-18$ a 6$)$,

2. outline of the defense ( $A p .18$ a $7-19$ a 7 ),

3. defense proper ( $A p .19$ a $8-24$ b 2) which can be divided into:

a. defense against caricature (Ap. 19 a $8-24$ b 2),

b. defense against the formal charges (Ap. 24 b 3-28 a 1),

4. digression on the divine mission of Socrates (Ap. 28 a 2-34 b 5),

5. epilogue (Ap. 34 b 6-35 d 8),

6. Socrates' proposal of a counterpenalty ( $A p .35$ e $1-38$ b 9),

7. closing speech ( $A p .38 \mathrm{c} 1-42$ a 5$)$.

The rhetorical and philological approach is not unimportant. It shows that there is a very close linguistic similarity between Plato's work and the Apology of Palamedes written by Gorgias from Leontinoi, although these two writings present two opposing

${ }^{1}$ H. Reader (1905: 89): „Wenn unter den Schriften Platons eine als geschichtlich getreu angenommen werden darf, so ist es die Apologie. Es läßt sich freilich nicht behaupten, daß Platon in der Apologie auch nur Absicht gehabt habe, über die von Sokrates von dem Gericht gehaltene Rede ein wirkliches Referat zu geben“. See also: Guthrie 2000: 6-69; Reale 1993: 303-310; Gajda 1993: 19 - 37. 
philosophical positions (Coulter 1964; Nerczuk 2005). The Apology also presents a good example of Socratic irony, because, while on the one hand, Socrates says that he is not a good orator and that he will speak as he usually did on the street of Athens, he uses the traditional rhetorical tools on the other. Such conduct, however, is directed against rhetoric; it can be regarded as its parody (Feaver \& Hare 1981: 205-216; Lewis 1990: 359-366), because Socrates wants rather to present his own personality than to win a lawsuit ${ }^{2}$.

The significant role of time is revealed in the Apology from the very beginning. Just "now" ( $v \tilde{v} v-A p .17 \mathrm{~d} 2$ ), on this specific day and time, Socrates appears in court for the first time. Not only the fact but also the time is notable, because it seems that only an extraordinarily righteous man would never during his whole life have to answer to the citizens of Athens for his deeds. This could imply that it is only possible for someone who shunned public and political life, but such would be an erroneous impression. It would be inconsistent with the facts presented in subsequent parts of the speech. Not only did Socrates, when he was a member of the Council of Five Hundred, go against the illegal death sentence passed on six of ten generals, because they left dead bodies of Athenian warriors without interment. He also, as is well-known, refused the unjust arrest of Leon of Salamina while the Thirty Tyrants were in power (Ap.32 a 9-d 8). Socrates, however, is forced now to exonerate himself from charges for the first time; he is acquainted with the rhetoric used during trials, but he had never practiced it. But the uniqueness of this time - this now, does not compel him to unique behaviour. Just the opposite, a defendant would like to make a speech as usually made on the street and squares of Athens. The current unchanging form of his conduct is certainly based on truth, which is contained not only in his words ( $A p .18$ a 1-6), but also, as hall be demonstrated further, in his unchanging way of life.

The first listed indictments state that Socrates is a sage and

1. he is a deep thinker ( $\left.\varphi \rho \nu \tau \tau \sigma \tau \eta S^{3}\right)$ and conducts research into the things above and beneath the earth, which has a lack of faith as a consequence;

2. he makes the weaker argument the stronger ( $A p .18 \mathrm{~b})$.

These are serious charges, especially as "the accusers are many and have been making

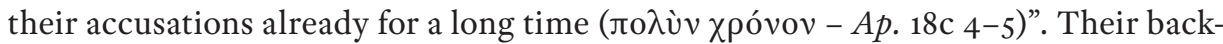

2 Socrates could have learned rhetoric but need not have. He could have taken part in different cases as an adult and become acquainted with the general rules of rhetoric in this "natural" way. As we know from the Pseudo-Xenophont's treatise Constitution of Athenians (III 2), Athenians "handle more public and private lawsuits and judicial investigations than the whole of the rest of mankind; the Boule has the multifarious business to deal with concerning war, revenue, legislation, the day-to-day affairs of the city and matters affecting their allies..." (Moore 1975).

3 This term appears only twice in the genuine works of Plato (Ap. 18 b 7; Cri. 48a 5). It is used also by Xenophon, but only in his Memorabilia (IV 7, 6) and Symposium (VI 6, 4; VI 7, 1, VII 2, 5). For more about the relationship between Plato's and Xenophon's Apologies see for example Shero (1927). 
ground can naturally be seen in Aristophanes' work Clouds ${ }^{4}$, which allows us to state that Socrates was accompanied by such opinions for 24 years at least. There can be found allusions to the philosophical conceptions of Anaxagoras, Protagoras, Diogenes of Apolonia and Antiphon, but only the first is explicitly mentioned in Plato's Apology. The first two names are worthy of note, because both Anaxagoras and Protagoras were persecuted for their convictions and had to escape from Athens (Mansfeld 1980: 17-95; Kerferd 1981: 43). Socrates realizes his situation is hopeless, because in a short time (ỏ $\left.\lambda \hat{i} \gamma \omega \chi \rho \rho^{\prime} \nu \omega\right)$ i.e. 1 day $^{5}$ - he must eradicate the prejudices concerning himself from the consciousness

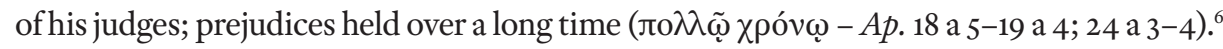
During his defence against being a philosopher of nature who disregards traditional Greek religion, this time is extended to Socrates' whole intellectual life by the statement that nobody could ever ( of Anaxgoras' thought. What's more, philosophy of this kind is called paradoxical (ätoлa övтa-Ap. $26 \mathrm{~d} 6-\mathrm{e} 2)$ ?

Socrates tries to find then the real basis for the charges and he proposes a thesis

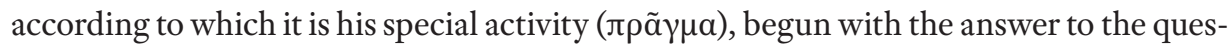
tion asked by Chaerephon to the oracle in the Delphi. An announcement that nobody is wiser than Socrates has met with his disbelief, although one thing is certain, namely, the god cannot lie. So the answer should be properly understood. He starts to explain what

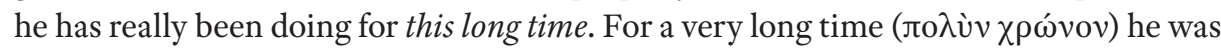
unable to grasp the meaning of the oracle and he has started to attain it with a great effort ( $\mu$ ó $ı \varsigma$ лá $v v$ ). He did not remain passive and self-satisfied in the face of the oracle, but he

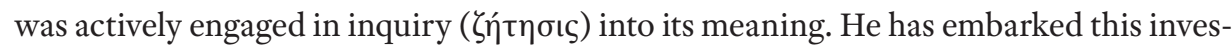
tigation from himself and has realized that he is wise neither in matters great nor small. How then is it possible that no other person could be wiser? He has entered into dialogue with the citizens of Athens, and especially with the members of those social groups which were held in high regard by Athenians, namely, politicians, poets, and craftsmen. During the effort it has also become manifest that Socrates' conduct had led to hatred toward him. This hatred will probably accompany him and he must presumably bear it every day. ${ }^{8}$

The question of time appears when the value of poets is determined. In a short time ( $\dot{\mathcal{V}} v$ ỏ $\lambda \hat{i} \gamma \omega)$ Socrates becomes convinced that they do not deserve to be called wise at all.

4 This comedy was staged in $423 \mathrm{BC}$, but we do not have the first version, only the second one, which was rewritten by Aristophanes (MacDowell 1995: 113-149). On Socrates in this Aristophanic play see Vander Waerdt (1994).

${ }^{5}$ In ancient Athens every lawsuit should end during one day and every party has a restricted time to voice its opinion. The time was measured by a water clock see Harrison (1971: 161).

${ }^{6}$ For 30 years, if we accept a hypothetical date of receiving the answer from the Delphic oracle as $430 \mathrm{BC}$; cf. Guthrie 1969: 406 and Reeve 1989: 21.

7 See also Phd. 97 b 8-98 b 6 and Shero (1941).

8 This is what Diogenes Laertius (II 21, 5-7) says about the reaction of people to dialogue with Socrates: "And very often, while arguing and discussing points that arose, he was treated with great violence and beaten, and pulled about, and laughed at and ridiculed by the multitude. But he bore all this with great equanimity. So that once, when he had been kicked and buffeted about, and had borne it all patiently...”. We cannot be sure, if 
What they express is wise, because its source is the deity present in them, but they do not understand what they say. What is interesting is that the short time allows Socrates, who does not possess knowledge, to expose the ostensible highest wisdom of poets, which was attributed to them by the people. Socrates achieves then truth in the negative aspect (He knows that they are not wiser) and confirms the oracle in a short time. What is more, it appears that he is still in the process of examination himself, because, wishing to find the meaning of the poems and the wisdom of the poets, he would like to learn something from them at the same time ( $\ddot{\alpha} \mu a-A p .22$ b 5). If this something is a form of moral knowledge, then to see the possibility of learning something means, according to me, that Socrates does not yet discern that this kind of knowledge is impossible for human beings to possess, something that will be proved later.

Politicians, poets and craftsmen have a skill ( $\tau \varepsilon \dot{\chi} \chi \eta)$ and they pursue therefore some occupation - they have some profession. Socrates' activity seems to be fundamentally different from these professions. This difference is marked by the temporal plane, although it is put little ironically. A cause of the above-mentioned hatred of some Athenians toward Socrates was also the imitation of him by young people, especially those of rich families, because they have a lot of free time ( $\sigma \chi 0 \lambda \eta$ ). But Socrates describes his

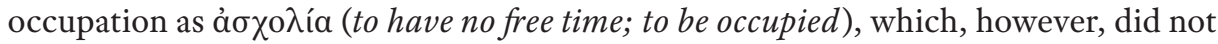
earn him a lot of money nor contribute to success in public life (Ap. 23 b 6-c 1). His activity then can be placed somewhere between the people who earn a living or accumulate a fortune, and people, who seem to be philosophers, but philosophise only in their free time, without taking responsibility for this activity, and without suitable divine sanction. The fullness of life is made manifest through Socrates' action. After having ended their work, the politicians, poets and craftsmen can come home and make something else. After having come home, young rich people have to stop philosophizing in the Socratic way, if they would like to stay rich. Only the son of Sophroniscus devoted his whole time to philosophy; he is between the above mentioned groups of people, but above them at the same time. His next words will specify a characteristic of the philosophical way of life, since in his summary explanation - what his activity consists in, what its causes and effects were - Socrates emphasizes a frankness and truthfulness in what he said. He is sure it is so, because his justification of his activity cannot be undermined now (vṽ $v)$ during the trial or in the future ( $\alpha \tilde{v} \theta ı \varsigma-A p .24$ b 1-2).

\section{II}

The next part of the Apology covers an exoneration of the charge of corruption of the youth levelled by Meletus. This exoneration is more a demonstration of Socrates' dialectical ability to trap the prosecutor than it is a real refutation of the charge (Brick-

this is not exaggerated, but we can suppose that aversion, contempt and maybe even physical violence have befallen Socrates. 
house \& Smith 1989: 112), which is turned against the prosecutor and expanded. It appears that Meletus:

1. makes fun seriously,

2. sues recklessly, and

3. maintains that he bothers about and takes care of things concerning which he

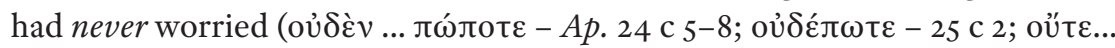
$\pi \omega ́ \pi о \tau \varepsilon-26$ b 2-3).

The uniqueness of now was earlier a cause for Socrates to not change his conduct, but now, when Meletus is obligated to answer questions, the prosecutor appears to judge him as being someone completely other up till that time. An analogy with horse training (and other animals) shows that only one person or a few can correct their condition. But Meletus claims something quite other, which indicates that he never takes heed about it. This leads to a division of men into two groups and to the thesis according to which contemptible and bad people always do evil, and good people always do good (Ap. 25 c 8-9; $25 \mathrm{~d}$ 10-e 1). A bad man lives in temporal asymmetry - he or she always does evil and never directs his or her attention to good, and a good man lives in temporal symmetry - he or she always does good and always direct his or her attention to evil to identify and avoid it. ${ }^{9}$ It is in accordance with the manner in which Socrates has presented his activity; it is necessary to put his or her own life through examination all the time to know what evil is and to avoid doing it.

The next charge against Socrates is that he is guilty of believing in other gods than those of the Athenian polis. This manner of wording the charge suggests that Socrates is guilty of infidelity, but as a result of the philosopher's prompting it is changed by Meletus himself into the charge of atheism. The questions of Socrates' attitude to religion and of his piety have stirred up controversy among researchers for a long time (e.g. Ferguson 1913; Anderson 1967; Vlastos 1999; Burnyeat 1997). It can be accepted that the son of Sophroniscus did not challenge the existence of gods nor the view that they are wisest and all-knowing, and he presents himself in the Apology as the soldier of Apollo after all. The now ( $v \tilde{v} v$ ) motif comes back in the course of discussion with Meletus. Now Socrates wants Meletus to make clearer the charge concerning the gods, because he is convinced that prosecutor should charge Anaxagoras rather than Socrates. The philosophical views

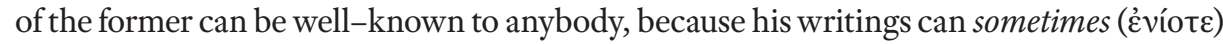
be bought at a very low price $(A p .26 \mathrm{~b} 8-\mathrm{e} 4)$. I think that sometimes should not be literally regarded only as concerning the value of Anaxagorean books. It could mean that presocratic philosophy is outmoded in the Athens of those times, so the writings of these philosophers can be purchased very cheaply. But I propose to understand it in a wider way as the expression of a very low estimation of human knowledge. It happens

9 I understand 'always' and 'never' in the natural temporal way, what in the classical manner can be presented as follows: always $=$ past + present + future; never $=\sim$ past $+\sim$ present $+\sim$ future. It should be remembered that 'always' can be understood also as timeless eternity. In this meaning it was used in philosophy to describe the principle(s) and the divine (Kolb 1974). 
that human beings have different beliefs concerning the gods (sometimes these are the opinions of the poets, sometimes of the philosophers for example, and they can also vary among members of the groups). It has also happened to Socrates, who probably has never stopped believing in the god(s), but the event provoked by Chaerephont has only allowed him to understand his faith better. Maybe this is why in the whole passage, where the charge of atheism is rejected, there is no use of temporal terms.

\section{III}

Having refused this charge, a digression takes place. Socrates seems to see that already the jury has practically given a verdict of guilty. He questions himself in the name of a personae fictae: "Are you then not ashamed, Socrates, of having followed such a pursuit, that you are now (vuví) in danger of being put to death as a result?" (Ap. 28 b 3-5). And again this now gives Socrates an opportunity to present his consistent character, which manifests itself through a persistent adherence to general law: one should keep the watch assigned by superior without regard to imminent danger. In the past Socrates has fought at Poteidaia, Amphipolis and Delion, where his superiors were men - his co-citizensand where he has demonstrated outstanding bravery. If in the case of an activity which has taken almost his whole adult life, the orders had came from a much higher rank, death cannot be a cause of desertion from the philosophical life (Ap. 28 d 6-29 a 1). This is why even if the judges were to release Socrates now and inflict a penalty of prohibition of doing his activity, he would never abandon his occupation (namely to spend his time

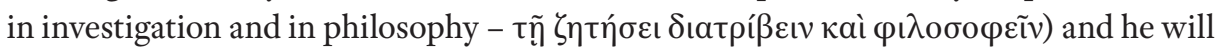
always exhort the Athenians to be better and better, and he will always put forward his arguments (Ap. $29 \mathrm{c} 1-\mathrm{d} 6) .^{10}$

The digression, however, is connected with the main course of argumentation in some way, because it alludes, inter alia, to the assessment of Meletus as an evil person. So this evil is not something abstract, but it is present now and it seems to work against the honest citizen. But Socrates is protected against this kind of evil by his character and by his way of life, because it not permitted according to the (divine) law for "a better man to be injured by a worse" $(A p .30 \mathrm{c} 9-\mathrm{d} 1){ }^{11}$ It characterizes only the passive aspect of the situation, to which Socrates' attitude is not limited. A role reversal comes about between Meletus and Socrates. In the face of evil the latter becomes now and officially the active defender of the city. He has performed this function de facto for many years, trying to

10 This fragment can be interpreted in two ways: (a) Socrates will be acquitted of charges, but he will be banned from philosophizing; (b) Socrates will be pronounced guilty, and he will be sentenced to being banned from philosophy. I prefer the (b) interpretation, pace Brickhouse \& Smith (1989: 143-147).

${ }^{11}$ We deal not only with some kind of formal conformity to the legal articles in this case, but also with the impossibility of going against the law, so the law cannot be enacted by mortals, but only by god. Socrates has already mentioned earlier that it is contrary to the law for Apollo to lie (Ap. $21 \mathrm{~b})$. See also Phdr. $256 \mathrm{~d}$; (Reeve 1989: 151). 
eradicate evil, i.e. ignorance, from citizens so that beautiful Athens can become also a good city. This long-lasting activity was not occasional in its character, but has taken place always (ácí). A selfless commitment to moral improvement in the polis has carried with it serious consequences. He has neglected his personal matters and it has reduced the material well-being and status of his family, because he has never received remuneration for his activity $(A p .30 \mathrm{~d}-31 \mathrm{c})$.

Socrates' commitment and concern for Athens could be questioned by the charge of his lacking active and broad participation in political life. But there are two counter arguments, strictly connected with each other.

Firstly, it was objected to by his daimonion, which advises ever against and never recommends. Secondly, there was Socrates' experience with political matters. A daimonion would seem to be a great tool for a politician at first sight, because one could take right decisions and avoid wrong ones by using it. But this voice of god is solely subjective nobody except Socrates has ever heard it. It would be effective only when everybody voted and acted according to Socrates' beliefs. But this would place him in a privileged situation and threaten equality - the fundamental value of democratic life. His minimal practical engagement in politics ${ }^{12}$ appears to be almost disastrous for him during both the democratic and oligarchic governments. This argumentation shows again the moral stability of Socrates' character, because he has never committed injustice towards anybody (Ap. $31 \mathrm{~d}-32 \mathrm{~d})$.

From the point of view of our analysis it is interesting how Socrates tries a second time to defend himself from the charge of corrupting those young men who are considered as his pupils. He never was, however, anyone's teacher. He did not mislead youths by claiming that he had wisdom as the poets or politicians did, so no one was harmed by him. He has never forbidden anyone to hear what he has said, but he has never encouraged anyone to imitate his action. So he cannot bear the responsibility for this kind of fraud. Then if it is assumed that

1. teaching something is an active conduct by which positive knowledge is achieved as a result, and

2. to make somebody better means to be a good teacher of him or her, and to make somebody worse means to be poor teacher of him or her,

then Socrates' conduct is neither moral nor immoral, because if he is not a teacher he does not influence the moral level of anyone. Socrates has some influence on other people, but it is only a passive one, because his only goal was to remove ü $\beta$ ıı, i.e. to remove belief that someone knows something that he or she really does not (Ap. $32 \mathrm{e}-33 \mathrm{a})$. As someone

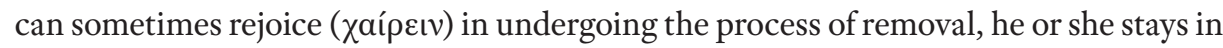

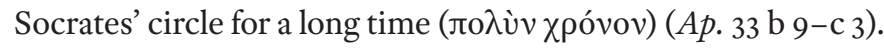

\footnotetext{
${ }^{12}$ It is, naturally, a minimal involvement in the official and formal political life of the Athens of the time. But Socrates' point of view on politics is quite different, and he realized it not in public, but in private life, because he was aware that the polis can be morally corrected only by a moral correction of every individual citizen; see Reeve 1989: 155-160.
} 
The first vote and the proposal of a punishment takes place after a short epilogue, where the attention of the judges is drawn to defendants' exceptional conduct during the trial. ${ }^{13}$ The significance of the present time (vṽv - Apol. 36 a 5-7) is stressed twice after the guilty finding is pronounced. Socrates is sentenced now only by thirty votes and he is now convinced that he really has defended himself against Meletus' charges. The verdict

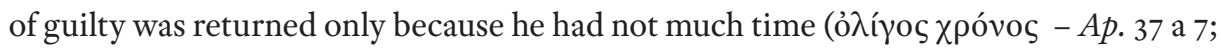
$37 \mathrm{~b} 2$ ) to present his argumentation and to convince the court. If the trial were to run a few days, the judges would not only be convinced of Socrates' innocence, but also that he deserves to be supported by the state. This suggestion (or maybe provocation) probably enraged many of the jurors, and in the second vote, as is well known, Socrates was sentenced to death.

\section{IV}

Plato's version of events ends with the closing speech, which links the beginning and the end of the work, also in a time perspective. It attracts attention to Socrates' statement

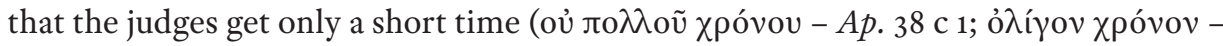
Ap. $38 \mathrm{c} 5$ ), which is certainly an accurate description of the time between the trial and the natural death of Socrates. It seems to be a special counterpoint to the oft-repeated argument that the defendant has too little time to prove his innocence. So, the time of life to the natural death Socrates would have had is compared to one day. As was said, the profit is not too big, but it appears that loss is huge. To carry out the sentence will be a cause of derogatory remarks about the Athenian polis on the one side, and it is now ( $v \tilde{v} v-A p .39 \mathrm{~b}$ ) that the citizens of Athens waste a chance of improving their moral level while the accusers "go convicted by truth of villainy and wrong" (Ap. 39 b 5-6), on the other.

The actions of the Athenians, immersed in time, are clearly characterized pejoratively, but time can also play a positive axiological role in human actions. Socrates shows how intensive the life of a human being must be who devotes a lot of time to develop him or herself so as to achieve that virtue comprehended naturally as a lack of ü $\beta$ ı. He or she should use every moment of his or her life to do it. Socrates does it even in the short time between the end of the trial and taking the prisoner to jail. Just then, at this

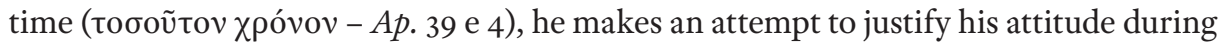
the trial. As the past - i.e. perceiving Socrates through the grotesque spectacles of the

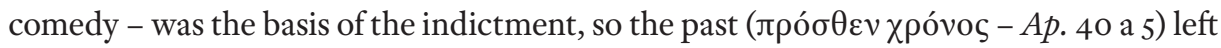
its imprint on his behaviour on the day of trial. Always (ácí) in the past, when he had to take steps aimed at something erroneous, the voice of the daimonion had advised against

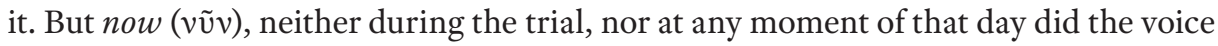
of god do so. Thus, the conduct of Socrates cannot be acknowledged as unjust, and its

\footnotetext{
13 See Platon 2003: 168 -172.
} 
consequence - the death penalty - as evil. This theological sign or proof is enhanced by

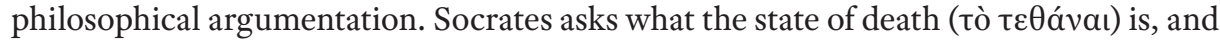
gives a dichotomous answer ( $A p .40 \mathrm{c} 4-9)$ :

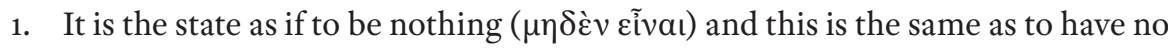

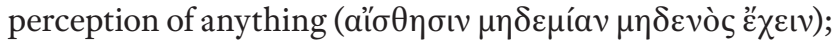

2. It is some kind of change of soul and transition to another place ( $\mu \varepsilon \tau \alpha \beta о \lambda \eta \dot{~ \tau \iota \varsigma ~ . . . ~}$

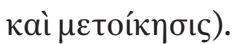

The first answer is substantiated by an analogy with the modi of day (day and night). If a time of life were to be understood as divided into days and nights, the state of death,

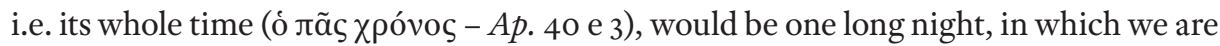
sleeping without dreams. Socrates claims that this kind of night is something better and

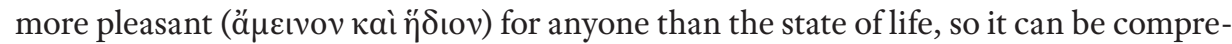
hended rather as an advantage than a disadvantage. One could have many reservations about this argument. First of all, one might ask whether it is reasonable to describe the aperceptual state as pleasant, because it can be said that aï $\sigma \theta \eta \sigma \varsigma$ makes it possible to feel pleasure. Sleep can be taken for pleasant only when someone wakes up fresh, rested and full of life (Roochnik 1985: 214). It can be considered whether there is a context in which the argument (or its parts at least) seems to be sensible. Firstly, we can assume that Socrates implicite appeals to the traditional, poetical view of human fate, according to which death is considered as setting one free from everyday efforts. Let make some assumptions:

1. The bivalent way of thinking;

2. Human life in the phenomenal world cannot be perfectly good (pleasant), because it always contains some hardships, and it is so, because desire is always the result of perceiving and this desire can be fulfilled only with effort, which is something unpleasant.

So, the aperceptual state (i.e. a state without desires) has to be better than the mixed form of life. ${ }^{14}$

Secondly, it should be pondered if an aperceptual state carries with it a lack of any feeling. Certainly, anyone in it cannot experience anything connected with aí $\theta \eta \eta \sigma \mathrm{s}$ in the strict sense. But we can find arguments, in which the possibility to feel and to perceive something appears, in both ancient rhetorical ${ }^{15}$ and poetical works (Pi. $O$.

${ }^{14}$ At the end of the Apology Socrates claims (41 d 3-5): "I see plainly that it was better for me to die now

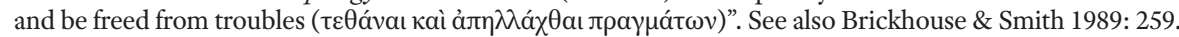

15 Isocr. Aegineticus (XIX) 42, 1-7: "How this woman and myself conducted ourselves toward Thrasylochus and Sopolis you have, in the main, heard; but perhaps they will have recourse to the one argument which remains to them - that Thrasyllus, the father of this woman, will feel that he is being dishonoured (if the dead have any perception of happenings in this world) when he sees his daughter being deprived of her fortune and me becoming the heir of what he had acquired" (Isocrates 1945).

Lycurg. In Leocr. 136, 1-7: "I believe myself that if the dead have any knowledge of earthly affairs, his own father, now no more, would be a sterner judge than any other" (Lycurgus 1962).

Lys. In Eratosth. (XII) 99, 4-100, 1: "Nevertheless, there is nothing lacking in my zeal - zeal for the sanctuaries that the defendants either sold or polluted by entering; zeal for the city that they weakened, for the shipyards that they destroyed, and for the dead; you may not be able to defend them during their lifetime, but 
$I I)$. What is important, however, is that both states - life and death - are temporal for Socrates. The first of them has a beginning and an end, and the second only a beginning. The first is diversified modo temporis into day and night, the second is undiversified. It seems that this is reflected at the axiological level. Life is axiologically diversified and it includes better and worse (pleasant and unpleasant) states, and death does away with the difference. The abolishment is the reason why the aperceptional state of being after death can be considered better than staying alive.

In the second answer death is interpreted as a change of place by souls. In the new

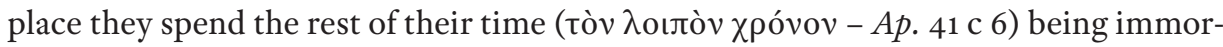
tal. This explains why they are happier than the souls remaining on earth ( $A p .41 \mathrm{c} 6)$. Axiologically important appears to be the activity on which he would spend his time

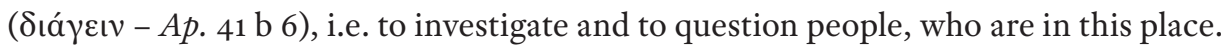
The passage enables Socrates to remove a barrier, which is put up by time in the phenomenal world. Socrates could spend time and talk with people, who had departed from this world. What's more, he would have an infinite time to test, "who among them is wise and who thinks he is when he is not" (Ap. $41 \mathrm{~b} 6-7)$. It would cause him to recognize himself as endlessly happy.

\section{Conclusions}

As can be seen from the above reconstruction, time is fully present in the Apology. Defending himself against the charges Socrates refers to its every aspect - past, present and future. On account of the peculiar nature of the event, which in Plato's text is depicted, time is evidently placed in an axiological context. Socrates stresses the importance of the present time very often. His right way of life is witness of his innocence and none of the judges is able to undermine it. It is precisely at that very moment that Socrates exposes again the moral weakness of the Athenian polis. Many citizens have no knowledge about ethical issues, but they act as if they had it, and they fall into ü $\beta \rho \iota c$, doing evil not only toward themselves, but also towards others. This is why Socrates now becomes an active public politician and the defender of the polis, and the Athenians have now lost the (last) chance to change their life into a better one. As was already said, the very peculiar context - the trial - causes Sophroniscus' son to emphasize the present time, but it is clear that what is happening now has happened also in the past. Since hearing the words of the oracle his life has been devoted to the moral improvement of himself and of all the people around him. Despite this purely historical limitation he can say that his activity has taken place always, because only during these thirty years was he fully aware of the true goal of his life and able to realize it thanks to the support of the divine power ( $\delta a \mu$ óvıov). But the always is not limited to the past and present. It also covers

you can assist them in death. It is my belief that they can hear us and that they will recognize you as you cast ballots" (Lysias 2000). 
the future. Therefore, when Socrates considers the possibility of exile, he says that it has

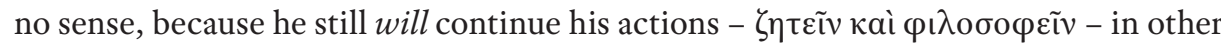
countries. As to be a philosopher is possible also in the 'new place', where the soul arrives having ended its earthly life, the always can be extended even to the time after death. It was already stated and it should be repeated now that the always reveals the true and real nature of the philosopher as the person of constant character. This kind of human being always searches for (moral) truth, always has the good in mind and always guards against doing evil. If to do evil is to maintain one has ethical knowledge and to try and teach this knowledge then it is clear that Socrates never did it. He never was a teacher of anyone and he never did harm anyone. The stability of character should concern every aspect of human life, especially one as important as the theological aspect. And this is why Socrates says that he was never an advocate of the Anaxagorean (i.e. atheistic) philosophy.

Some relativity can also be seen in relation to the assessment of the value of a given period of time. In the Apology there appears quite often an opposition between long and short times. Socrates is aware that the moral presuppositions concerning himself have long been present in the minds of the Athenians and that he has a short time to defend himself. This can be interpreted as a blatant injustice, on the one hand, because everyone should be aware that it is very difficult to debunk deep-rooted superstitions. But on the other hand the first vote reveals that the lengthy influence of the false and slandering images (like those of Aristophanes) was not so deep, because Socrates was sentenced by only a small number of voices. The contrast between long and short times could be also seen in Socrates' encounter with the poets. The latter were highly esteemed among the Greeks for a long time (Crotty 2009; Barfield 2011). It did not take long, however, to expose not only their epistemological weakness - they could not explain what they say but also, and especially, their immorality. For according to Socrates' moral standards they were overflowing with ü $\beta \rho ı \varsigma$ deciding on matters about which they have not the foggiest idea.

Finally I would like to mention two axiological dimensions of time. The first is the value of the length and shortness of its period without opposition. As we have seen, for a long time Socrates did not understand the real meaning of the answer given by the oracle, and he made inquiries to interpret it. It can be said that he has searched for its sense during his entire life, and - what is more important - this has taken place with great effort ${ }^{16}$. It seems that this experience is conditio sine qua non of philosophical progress. The crowning achievement of this development is the joy which appears when ü $\beta$ เ purged from someone's life. But as in the case of Socrates it takes a lot of time. This joy in its positive dimension can be achieved during someone's life, and after death in the negative dimension, when freedom from every effort is attained. What is more, this effort should probably take up every moment of our life, as Socrates shows using even the short time of the judges' council to philosophise. (1990)

${ }^{16}$ Effort becomes one of the highest values in Antisthenes' philosophy; see SSR V A 85, 97 Giannantoni 


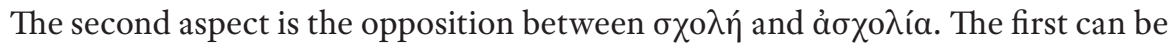
understood as 'to have free time', and the second as 'to spend time'. I have argued that Socrates is somewhere between and above people who spend their time in earning

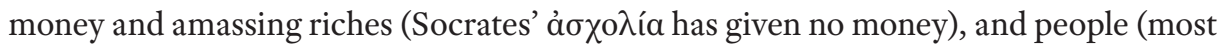
of whom were young), who have a lot of free time, who philosophise, but probably only in their free time and without the proper (divine) sanction. But it should be stressed that Socrates transforms the meanings of these two words. During the provocation of the court he says that he needs more free time to encourage people to become better (Ap. $36 \mathrm{~d}$ 5), meaning that he needs to be free from the bother of existential necessities, but in this so-called 'free time' he will actually be working, because his real á $\sigma \chi 0 \lambda i ́ a$ is to philosophise and to make inquiries into who is wise and who is not. This is work of immense importance for every state, it is true politics, and it could be done almost for free - the only salary is to provide a daily meal. 


\section{BIBLIOGRAPHY}

ANDERSON, D.E., 1967, “Socrates' Concept of Piety”, JHPh 5, pp. 1-13.

BARFIELD, R., 2011, The Ancient Quarrel between Philosophy and Poetry, Cambridge.

Brickhouse, T.C. \& SMith N.D., 1989, Socrates on Trial, Princeton.

Burnyeat, M.F., 1997, “Impiety of Socrates”, AncPhil 17, pp. 1-12.

Callahan, J.F., 1948, Plato. Time, the Moving Image of Eternity, in: J.F. Callahan, Four Views of Time in Ancient Philosophy, Cambridge, pp. 3-37.

Coulter, J.A., 1964, “The Relation of the Apology of Socrates to Gorgias' Defence of Palamedes and Plato's Critique of Gorgianic Rhetoric”, HSPh 68, pp. 269-303.

Сrotтy, K., 2009, The Philosopher's Song. The Poets' Influence on Plato, Lanham-Boulder-New York-TorontoPlymouth UK.

Diogenes LAERTIUs, The Lives and Opinions of Eminent Philosophers, transl. C.D. Yonge, London, 1853.

FEAVER, D.D., HARE, J.E., 1981, “The Apology as an Inverted Parody of Rhetoric”, Arethusa 14, pp. $205-216$.

FERguson, A.S., 1913, The Impiety of Socrates, CQ7, pp. 157-175.

GAJDA, J., 1993, Platońska droga do idei. Aksjologiczny rodowód platońskiej ontologii, Wrocław.

Giannantoni, G., 1990, Socratis et Socraticorum reliquiae, vol. II, Napoli.

GuTHrie, W.K.C., 1969, A History of Greek Philosophy, vol. III: The Fifth-Century Enlightenment, Cambridge.

Guthrie, W.K.C., 2000, Sokrates, tłum. K. Łapiński, S. Żuławski, Warszawa [A Polish translation of Idem, Socrates, Cambridge 1971].

Harrison, A.R.W., 1971, The Law of Athens. Procedure, Oxford.

IsocrATES, 1945, vol. III, transl. L. van Hook, Cambridge MA and London.

KerferD, G.B., 1981, Sophistic Movement, Oxford.

LEwIS, T.J., 1990, "Parody and Argument from Probability in the Apology”, Ph\& Lit 14, pp. 359-366.

LlOYD, G.E.R., 1987, Czas w myśli greckiej, transl. B. Chwedeńczuk, in: Czas w kulturze, A. Zajączkowski (red.), Warszawa 1987, pp. 207-258 [A Polish translation of Idem, Views on Time in Greek Thought, in: L. Gardet et al. (eds.), Cultures and Time, Paris, 1976, pp. 117-148].

LyCURgus, 1962, in: Minor Attic Orators, vol. II, transl. J.A. Burtt, M.A., London and Cambridge MA.

Lysias, 2000, transl. S.C. Todd, Austin.

MacDowell, D.M., 1995, Aristophanes and Athens. An Introduction to the Plays, Oxford.

MAnsfeld, J., 1980, “The Chronology of Anaxagoras' Athenian Period and the Date of His Trial”, Mnemosyne 33, pp. 17-95.

Moore, J. M., 1975, Aristotle and Xenophon on Democracy and Oligarchy, Berkeley and Los Angeles.

Nerczuk, Z., 2005, „Retoryczność Platońskiej Obrony Sokratesa”, Studia Antyczne i Mediewistyczne 3 [38], pp. 43-48.

Plato, Euthyphro, Apology, Crito, Phaedo, Phaedrus, transl. H.N. Fowler, Cambridge MA and London, 1996.

Platon, 2003, Obrona Sokratesa, R. Legutko (transl. \& comm.), Kraków.

READER, H., 1905, Platons philosophische Entwickelung, Leipzig.

REAle, G., 1993, Historia filozofii starożytnej, t. 1: Od początków do Sokratesa, transl. E.I. Zieliński, Lublin [A Polish translation of Idem, Storia della filosofia antica, vol. I: Dalle origine a Socrate, Milano 1979].

REEVE, C.D.C., 1989, Socrates in Apology. An Essay on Plato's Apology of Socrates, Indianapolis.

Roochnik, D.L., 1985, “Apology 40c 4-41e 7: Is Death Really a Gain?”, CJ 80, pp. 212-220. 
SHERo, L.R., 1927, “Plato's Apology and Xenophon's Apology”, CW*20, pp. 107-111.

Shero, L.R., 1941, “Apology 26 d-e and the Writings of Anaxagoras”, CW*35, pp. 219-220.

VANDER WAERdt,P.A., 1994, “Socrates in the Clouds”, in: P.A. Vander Waerdt (ed.), The Sophistic Movement, Ithaca and London.

Vlastos, G., 1999, “Socratic Piety” [w:] G. Fine (ed.), Plato 2: Ethics, Politics, Religion and the Soul, Oxford, pp. 56-77.

A R T UR PACEWICZ

/Wroctaw /

\section{Ethical Dimension of Time in Plato's Apology of Socrates}

The aim of the present article is to analyse the Apology in its aspect of time. When defending himself against the charges, Socrates appeals to the past, the present and the future. Furthermore, the philosopher stresses the meaning of the duration of time. Thus, the seems to suggest that all really important activities demand a long time to benefit, since they are almost invariably connected with greater efforts. While the dialogue proves thereby to be an ethical one, the various time expressions also gain an ethical dimension.

Socrates, the Apology, the ethical dimension of time 